\title{
Anthropogenic alteration of available, amorphous, and total iron in an Andisol from dairy slurry applications over a 12-year period
}

\author{
Christian Guajardo ${ }^{1,2}$, José Manuel Recio-Espejo ${ }^{1}$, Marco A. Sandoval ${ }^{2^{*}}$, Fernando Díaz del Olmo ${ }^{3}$, \\ María Bustamante ${ }^{2}$, and Alfonso García-Ferrer ${ }^{4}$
}

\begin{abstract}
'Universidad de Córdoba, Facultad de Ciencias, Campus Universitario de Rabanales, Carretera Madrid km 396, 14071-Córdoba, España. ${ }^{2}$ Universidad de Concepción, Facultad de Agronomía, Av. Vicente Méndez 595, Chillán, Chile.

"Corresponding author (masandov@udec.cl).

${ }^{3}$ Universidad de Sevilla, Facultad de Geografía e Historia, C/S. Fernando 4, CP 41004. Sevilla, España.

${ }^{4}$ Universidad de Córdoba, Departamento Ingeniería Gráfica y Geomática, Campus Universitario de Rabanales, Carretera Madrid km 396 , 14071, Córdoba, España.
\end{abstract}

Received: 23 September 2019; Accepted: 16 December 2019; doi:10.4067/S0718-58392020000100108

\begin{abstract}
Iron is one of the most abundant elements in agricultural soils, but it is mostly present in non-assimilable forms. The dynamics of Fe is determined by several factors, such as organic matter (OM). Dairy slurry is used to increase total OM content in soils. The objective of this study was to determine the effect of applying dairy slurry over a 12-yr period on the levels of available, amorphous, and total $\mathrm{Fe}$ in an Andisol soil as indicators of pedogenic alteration. The contents of available $\left(\mathrm{Fe}_{\mathrm{t}}\right)$, amorphous $\left(\mathrm{Fe}_{\mathrm{ox}}\right)$, and total $\left(\mathrm{Fe}_{\mathrm{t}}\right) \mathrm{Fe}$ were evaluated by selective extractions. A completely randomized experimental design with repeated measures was used, which consisted of six treatments $(2,4,6,8,10,12 \mathrm{yr})$ of slurry application and four replicates. A control treatment (no slurry application) was also included with permanent Lolium perenne L. and Trifolium repens L. grasslands. Dairy slurries were applied at a maximum rate of $150 \mathrm{~m}^{3} \mathrm{ha}^{-1}$. Slurry application in the soil significantly increased $\mathrm{Fe}_{\mathrm{d}}$ and $\mathrm{OM}$ contents up to $8 \mathrm{yr}$ in the $\mathrm{A}\left(8.2 \mathrm{~g} \mathrm{~kg}^{-1}\right.$ and $\left.15.7 \%\right)$ and $\mathrm{B}$ (7.49 $\mathrm{g} \mathrm{kg}^{-1}$ and $10.3 \%$ ) genetic horizons under study; there was a positive correlation between $\mathrm{Fe}_{\mathrm{d}}$ and $\mathrm{OM}$. This would indicate that increased $\mathrm{OM}$ would accelerate the pedogenesis of this soil. In general, $\mathrm{Fe}_{\mathrm{d}-\mathrm{x} x}$ values were low and there was a significant decrease $(p \leq 0.05)$ in the 2-, 4-, and 6-yr treatments with values ranging between 1.0 and 0.7 for the $\mathrm{Fe}_{\text {ox:d }}$ ratio, indicating increased pedogenesis.
\end{abstract}

Key words: Andisol, iron, organic matter, slurry.

\section{INTRODUCTION}

The predominant soils in the central-southern zone of Chile are of volcanic origin. The forestry, agricultural, and livestock activities carried out in this area, along with the natural processes occurring in the soil, modify the chemical, physical, and biological properties of the soil. The Andisol and Ultisol orders are the most extensively used for agricultural purposes in this area (Pizarro, 2000). Andisols cover approximately 124 million ha worldwide and account for approximately $0.8 \%$ of the total land area (Tsai et al., 2010).

Soils derived from volcanic materials represent between $50 \%$ and $60 \%$ of the total arable land in Chile. These soils cover large areas under agricultural (cereal production) and livestock use. They also support a considerable part of the forests (Besoain, 1985). 
Volcanic ash soils have a number of unique properties that are directly attributable to the properties of the parent material (Shoji et al., 1993). They are characterized by a mineralogy dominated by non-crystalline components, such as clay minerals, organic matter $(\mathrm{OM}), \mathrm{Fe}$, and aluminum oxides. This provides these soils with distinctive characteristics, such as $\mathrm{pH}$-dependent charges and electrolyte concentration present in the solution (Moustakas and Georgoulias, 2005). These distinctive properties largely favor the formation of amorphous materials and organic C (OC) accumulation, which are the main pedogenic processes in soils derived from volcanic ash. The clay fraction of these soils is dominated by the presence of allophane, para-allophanic components, imogolite, and several phyllosilicates (smectites, chlorites) in different amounts; these are products of the weathering of pyroclastic materials from recent volcanic deposits (Besoain, 1985).

Iron plays an important role within the mineralogy of these soils and can explain part of the pedogenic processes. It is used as an indicator of the environmental conditions in which soil is formed and developed (Sánchez and Rubiano, 2015). Varying amounts of $\mathrm{Fe}$ are found in the soil, but levels are usually high. It is the most abundant microelement in the soil, but only a small fraction corresponds to assimilable forms in most cases (Solís, 1998). Therefore, Fe is scarcely available because it can easily change its oxidation state and form insoluble hydroxides (Harrington and Crumbliss, 2009). It can form Fe-humus complexes, oxides (crystalline and non-crystalline), and ferromagnesium silicates (Aguado-Santacruz et al., 2012). Magnetite, goethite, hematite, and ferrihydrite are highly crystalline Fe minerals, whereas minerals with little or no crystalline structure are called amorphous oxyhydroxides (Torrent et al., 1980). The weathering of these primary minerals releases $\mathrm{Fe}$ to the soil solution where it can be used by organisms, form part of different organic complexes, or form secondary minerals, such as sulfides, carbonates, clay minerals, but mainly oxides and hydroxides. These minerals have different compositions and degree of crystallization, which control Fe solubility in the soil (Murad and Fischer, 1988). The Fe oxides, which include hydroxides, oxides, and oxyhydroxides, promote aggregation, adsorption of nutrients and contaminants, and also serve as electron receptors (Stoppe et al., 2015). Therefore, it is important to understand the composition of the soil and sedimentary Fe pools.

The dynamics and availability of $\mathrm{Fe}$ are governed by the amount and type of clay present, $\mathrm{pH}$, texture, and aeration of the soil. Organic matter is an important factor in the Fe availability because it forms stable compounds that generate the so-called chelates (soluble organic complexes of Fe) (Solís, 1998). Organic matter favors growth of microbial populations, which can consume oxygen under waterlogging conditions or decompose OM to release Fe from organic compounds in forms that can be assimilated by plants (Aguado-Santacruz et al., 2012).

The application of dairy slurry to the soil is a common fertilization practice; it can meet the total or partial fertilization requirements of permanent grasslands in southern Chile (Salazar et al., 2003) and provide microelements. Its use in soils with low OM content represents a valuable resource to increase this parameter (Salazar et al., 2007).

The Fe contents can be determined by physical and chemical methods. Physical methods include X-ray diffraction, differential thermal analysis, Mössbauer spectroscopy, and infrared spectroscopy (Hernández and Meurer, 1997). Chemical extraction approaches include the dithionite-citrate-bicarbonate (DCB) (Mehra and Jackson, 1960), ammonium oxalate $\left(\mathrm{Fe}_{\mathrm{ox}}\right)$, and sodium or potassium pyrophosphate methods. The DCB method (Mehra and Jackson, 1960) allows extracting available $\mathrm{Fe}\left(\mathrm{Fe}_{\mathrm{d}}\right)$, which represents most of the pedogenic $\mathrm{Fe}$ minerals (crystalline and amorphous), and determining labile Fe oxides (Vazques et al., 2014). The acid ammonium oxalate extraction method (Schwertmann, 1964 ) is used to estimate the amount of amorphous or poorly crystalline Fe in soils and sediments. The sodium or potassium pyrophosphate method is commonly used to extract Fe from soil organic complexes (Smith, 1994). Some Fe ratios are used to determine the presence of these minerals in the soil. For example, $\mathrm{Fe}_{\text {ox:d }}$ is a measurement of the amount of total pedogenic $\mathrm{Fe}$, while the difference, $\mathrm{Fe}_{\mathrm{d}-\mathrm{x}}$, is used to estimate crystallized $\mathrm{Fe}$ (goethite and hematite) (AcevedoSandoval et al., 2002).

The objective of this study was to determine the effect of applying dairy slurry over a 12-yr period on the levels of available, amorphous, and total $\mathrm{Fe}$ in an Andisol soil as indicators of pedogenic alteration. 


\section{MATERIALS AND METHODS}

\section{Study site}

The study was conducted at the Livestock Experimental Station of the Universidad de Concepción (36 33'17" S, $71^{\circ} 52^{\prime} 45^{\prime}$ W), Chillán, Nuble Region, Chile. It is located in the central depression of the country and has a temperate Mediterranean climate with a mean annual temperature of $13.9^{\circ} \mathrm{C}$ and a minimum of $3{ }^{\circ} \mathrm{C}$ during July and a maximum of $28.6^{\circ} \mathrm{C}$ in January. Mean annual rainfall is $1025 \mathrm{~mm}$.

The soil is a Humic Haploxerands (Arrayán Series) (Stolpe, 2006). The experimental site has a predominantly silt loam texture. The soil is well-structured on the surface with high porosity associated with good rooting in the whole pedon (Table 1). It has a flat or almost flat topography with moderate permeability and slow surface runoff.

\section{Experimental design}

A completely randomized design with repeated measurements was used, consisting of six treatments and four replicates per treatment. A control treatment (untreated) was also included. The experimental unit was a 1 ha $\left(10000 \mathrm{~m}^{2}\right)$ plot. The treatments were T0 (control with no slurry application), T2 (2-yr slurry application), T4 (4-yr slurry application), T6 (6-yr slurry application), T8 (8-yr slurry application), T10 (10-yr slurry application), and T12 (12-yr slurry application).

Table 1. Chemical and physical characterization of the studied Andisol. Livestock Experimental Station, Chillán, Chile.

\begin{tabular}{|c|c|c|}
\hline & \multicolumn{2}{|c|}{ Genetic Horizon } \\
\hline & Horizon A & Horizon B \\
\hline Moisture, \% & 15.11 & 13.13 \\
\hline Macropores, \% & 84.34 & 84.35 \\
\hline Micropores, \% & 0.55 & 2.25 \\
\hline Bulk density, $\mathrm{g} \mathrm{cm}^{-3}$ & 0.76 & 0.78 \\
\hline Water height, cm & 21.33 & 26.79 \\
\hline $\mathrm{pH}$ & 5.31 & 6.23 \\
\hline Organic matter, \% & 11.11 & 7.01 \\
\hline $\mathrm{NO}_{3}, \mathrm{mg} \mathrm{kg}^{-1}$ & 6.60 & 7.70 \\
\hline $\mathrm{NH}_{4}, \mathrm{mg} \mathrm{kg}^{-1}$ & 12.30 & 3.70 \\
\hline $\mathrm{P}, \mathrm{mg} \mathrm{kg} \mathrm{kg}^{-1}$ & 14.60 & 3.50 \\
\hline $\mathrm{K}, \mathrm{cmol} \mathrm{kg}^{-1}$ & 0.66 & 0.11 \\
\hline $\mathrm{Ca}, \mathrm{cmol} \mathrm{kg}^{-1}$ & 6.38 & 4.60 \\
\hline $\mathrm{Mg}, \mathrm{cmol} \mathrm{kg}^{-1}$ & 1.85 & 0.81 \\
\hline $\mathrm{Na}, \mathrm{cmol} \mathrm{kg}^{-1}$ & 0.36 & 0.41 \\
\hline Bases, cmol kg-1 & 9.25 & 5.93 \\
\hline $\mathrm{Al}$ Int, $\mathrm{cmol} \mathrm{kg}^{-1}$ & 0.09 & 0.03 \\
\hline ECEC, $\mathrm{cmol} \mathrm{kg}^{-1}$ & 9.34 & 5.96 \\
\hline Saturation Al, \% & 0.97 & 0.56 \\
\hline Saturation K, \% & 7.07 & 1.84 \\
\hline Saturation $\mathrm{Ca}, \%$ & 68.30 & 77.15 \\
\hline Saturation $\mathrm{Mg}, \%$ & 19.80 & 13.51 \\
\hline $\mathrm{S}, \mathrm{mg} \mathrm{kg}^{-1}$ & 50.40 & 28.02 \\
\hline $\mathrm{Fe}, \mathrm{mg} \mathrm{kg}^{-1}$ & 64.20 & 28.00 \\
\hline $\mathrm{Mn}, \mathrm{mg} \mathrm{kg}^{-1}$ & 14.84 & 3.74 \\
\hline $\mathrm{Zn}, \mathrm{mg} \mathrm{kg}^{-1}$ & 0.88 & 0.06 \\
\hline $\mathrm{Cu}, \mathrm{mg} \mathrm{kg}^{-1}$ & 1.56 & 0.90 \\
\hline $\mathrm{B}, \mathrm{mg} \mathrm{kg}^{-1}$ & 0.60 & 0.17 \\
\hline Sand, \% & 39.30 & 43.60 \\
\hline Silt, \% & 38.40 & 40.70 \\
\hline Clay, $\%$ & 22.30 & 15.70 \\
\hline Texture & Loamy & Loamy \\
\hline Real density, $\mathrm{g} \mathrm{cm}^{-3}$ & 2.59 & 2.57 \\
\hline Dry color, & 7.5YR 5/2 & 7.5YR $6 / 4-10$ YR $6 / 3$ \\
\hline Wet color, & $10 \mathrm{YR} 2 / 1$ & 7.5YR 3/3-10 YR 3/2 \\
\hline Profile depth, cm & 11.3 & 30.9 \\
\hline
\end{tabular}

Al Int: Exchangeable aluminum; ECEC: effective cation exchange capacity. 
Slurry was accumulated in an open air lagoon (10 m long, $2 \mathrm{~m}$ wide, and $1.5 \mathrm{~m}$ deep) with a $15000 \mathrm{~L}$ capacity and applied at a mean rate of $15 \mathrm{~m}^{3} \mathrm{ha}^{-1} \mathrm{yr}^{-1}$ using a cart with a $5000 \mathrm{~L}$ capacity. The slurry used in this study complies with the provisions of "Emission standard for the regulation of pollutants associated with liquid waste discharges to marine and inland surface waters in Chile", which ensures the composition of waste over time, originating from a homogeneous and constant flock, number of animals, breed, diet, and winter housing period (Table 2). On average, slurry was applied every $15 \mathrm{~d}$. The experiment was conducted on permanent Lolium perenne L. and Trifolium repens L. grasslands. For maintenance fertilization, fertilizers were applied at rates of $46 \mathrm{~kg} \mathrm{~N} \mathrm{ha}^{-1}, 120 \mathrm{~kg} \mathrm{P} \mathrm{ha}^{-1}$, and $60 \mathrm{~kg} \mathrm{~K} \mathrm{ha}^{-1}$.

\section{Sampling}

A test pit was dug on each hectare plot in each treatment to identify genetic horizons and determine the depth and morphological characteristics for pedogenic horizon differentiation (A and B) (Table 1). Twenty-five subsamples were randomly taken from the soil with a cylindrical soil sampler, thus forming a homogeneous sample for each hectare in each treatment and pedogenic horizon. Therefore, each treatment consisted of four combined samples, which were placed in polyethylene containers and sent for analysis. Soil samples were dried at room temperature, sieved through a $2 \mathrm{~mm}$ sieve according to the procedure described by Sandoval et al. (2012), and then analyzed.

\section{Soil chemical analysis}

Extraction of different forms of Fe. The DCB method proposed by Mehra and Jackson (1960) was used to selectively extract available Fe oxides. A $2 \mathrm{~g}$ homogenized and previously sieved soil sample $(<2 \mathrm{~mm})$ was weighed on an analytical balance (model L5201, BEL Engineering, Monza, Italy). A $50 \mathrm{~mL}$ solution of $\left(\mathrm{NH}_{4}\right)_{2} \mathrm{C}_{6} \mathrm{H}_{6} \mathrm{O}_{7}(0.26 \mathrm{M})-\mathrm{NaHCO}_{3}(0.11$ $\mathrm{M})$ and $1 \mathrm{~g}$ of sieved soil were placed in an Erlenmeyer flask and agitated for $16 \mathrm{~h}$ in a shaking incubator (BJPX-Wichita, Biobase, Jinan, China) at $120 \mathrm{rpm}$ and $25^{\circ} \mathrm{C}$. The mixture was filtered through filter paper (Whatman $\mathrm{Nr} 42,125 \mathrm{~mm}$ ) and stored in a polyethylene jar until the samples were read in an atomic absorption spectrophotometer (AAS). To extract amorphous Fe oxides, $2 \mathrm{~g}$ homogenized and previously sieved soil $(<2 \mathrm{~mm})$ were weighed on an analytical balance (BEL Engineering) and mixed with $50 \mathrm{~mL}$ extractant $\left(\mathrm{NH}_{4}\right)_{2} \mathrm{C}_{2} \mathrm{O}_{4} \times \mathrm{H}_{2} \mathrm{O}(0.2 \mathrm{M})$ at $\mathrm{pH} 3.0$ in a $100 \mathrm{~mL}$ Erlenmeyer flask according to the method described by Schwertmann (1964). The solution was agitated in a shaking incubator (Biobase) in the dark at $120 \mathrm{rpm}$ and $25^{\circ} \mathrm{C}$ for $120 \mathrm{~min}$. Once the agitation period was complete, the mixture was filtered through filter paper (Whatman $\mathrm{Nr} 125,125 \mathrm{~mm}$ ) and the extract was placed in a polyethylene container until the samples were read in an AAS. Calcination and acid digestion procedures were used to extract total Fe (Sadzawka et al., 2006).

Atomic absorption spectrophotometry (AAS). Based on Fe levels measured in AAS, 1:100 dilutions were made for all the evaluated forms of Fe. The lamp to analyze Fe and the light wavelength were selected in the AAS (GE503115, SOLAAR 969, Thermo Fisher Scientific, Waltham, Massachusetts, USA). The Fe patterns were determined, the calibration curve was performed, and the corresponding samples were read for different forms of Fe. Results were expressed in $\mathrm{g} \mathrm{kg}^{-1}$ of sample.

Table 2. Characterization of the studied dairy slurry (dry weight base, $\mathrm{mg} \mathrm{kg}^{-1}$ ).

\begin{tabular}{lr}
\hline Parameter & \\
\hline $\mathrm{pH}$ & 7.20 \\
Organic matter, \% & 77.70 \\
Moisture, \% & 85.40 \\
Dry matter, \% & 14.60 \\
$\mathrm{~N}, \%$ & 1.70 \\
$\mathrm{P}, \%$ & 0.31 \\
$\mathrm{~K}, \%$ & 0.61 \\
$\mathrm{Ca}, \%$ & 0.76 \\
$\mathrm{Mg}, \%$ & 0.22 \\
$\mathrm{Na}, \%$ & 0.05 \\
$\mathrm{Fe}, \mathrm{mg} \mathrm{L}^{-1}$ & 433.08 \\
$\mathrm{Mn}, \mathrm{mg} \mathrm{L}^{-1}$ & 34.56 \\
$\mathrm{Zn}, \mathrm{mg} \mathrm{L}^{-1}$ & 10.86 \\
$\mathrm{Cu}, \mathrm{mg} \mathrm{L}^{-1}$ & 3.30 \\
$\mathrm{~B}, \mathrm{mg} \mathrm{L}^{-1}$ & 3.88 \\
\hline
\end{tabular}




\section{Statistical analysis}

Data were subjected to ANOVA to test the significance of treatments. Differences between mean values were analyzed by Tukey's test at $95 \%$ confidence interval (SAS Institute, Cary, North Carolina, USA). The assumption of normality was tested by the Shapiro-Wilks test.

\section{RESULTS AND DISCUSSION}

\section{Selective extractions of available, amorphous and total $\mathrm{Fe}$}

The $\mathrm{Fe}_{\mathrm{d}}$ contents, which are labile Fe, varied between 4.55 and $9.85 \mathrm{~g} \mathrm{~kg}^{-1}$ in the A horizon and accounted for $14.63 \%$ to $29.09 \%$ of total $\mathrm{Fe}\left(\mathrm{Fe}_{t}\right)$ content (Table 3). These levels were lower than those observed by Lu et al. (2014) in an Ultisol with values up to $35.38 \mathrm{~g} \mathrm{~kg}^{-1}$. However, a recent study conducted by Kilic et al. (2018) reported similar values to those obtained in our work in soils of volcanic origin (Andisol). Significant differences $(p \leq 0.05)$ were found between all the treatments studied in the A horizon; $\mathrm{Fe}_{\mathrm{d}}$ levels increased in treatments $\mathrm{T} 2, \mathrm{~T} 4$, and $\mathrm{T} 6$, but decreased significantly in treatments T8, T10, and T12. A similar behavior was observed in the B horizon (Table 3). However, values in the B horizon were lower compared with the surface A horizon in all treatments. Acevedo-Sandoval et al. (2011) described a similar behavior in the distribution of Fe oxides in three soil profiles of volcanic origin in the Northwest Region of the State of Mexico.

Amorphous $\mathrm{Fe}\left(\mathrm{Fe}_{\mathrm{ox}}\right)$ are usually non-crystalline and poorly arranged compounds (Hernández and Meurer, 1997). The $\mathrm{Fe}_{\text {ox }}$ values were higher in the A horizon. These results concur with findings by Pérez et al. (2018), who conducted selective $\mathrm{Fe}$ extractions in an Andisol from eastern Antioquia, Colombia, and reported that the $\mathrm{Fe}_{\mathrm{ox}}$ content decreases as depth in the profile increases. The $\mathrm{Fe}_{\mathrm{ox}}$ content for the surface horizon varied between 5.23 and $7.79 \mathrm{~g} \mathrm{~kg}^{-1}$ (Table 3). Similar values were reported by Chevallier et al. (2010) in an Andisol in Martinique, French West Indies. Nonsignificant differences were found $(p \leq 0.05)$ in $\mathrm{Fe}_{\mathrm{ox}}$ levels between treatments $\mathrm{T} 0, \mathrm{~T} 2$, and $\mathrm{T} 12$. For the $\mathrm{B}$ horizon, $\mathrm{Fe}_{\mathrm{ox}}$ values varied between 3.03 and $7.34 \mathrm{~g} \mathrm{~kg}^{-1}$ and accounted for $9.78 \%$ to $23.72 \%$ of the $\mathrm{Fe}_{\mathrm{t}}$ content in the soil. The $\mathrm{Fe}_{\text {ox }}$ values increased in $\mathrm{T} 2$, T4, and T6 compared with the control. However, levels decreased significantly in T8 and T10, but increased again in T12. Acevedo et al. (2014) indicated that $\mathrm{Fe}_{\mathrm{ox}}$ is usually present in soils with $\mathrm{pH}$-dependent charges and a high $\mathrm{P}$ fixation

Table 3. Results of the selective extraction of $\mathrm{Fe}_{\mathrm{d}}, \mathrm{Fe}_{\mathrm{ox}}$, and $\mathrm{Fe}_{\mathrm{t}}$ for both the $\mathrm{A}$ and $\mathrm{B}$ genetic horizons of the studied Andisol.

\begin{tabular}{|c|c|c|c|c|}
\hline Horizon & Treatment & $\mathrm{Fe}_{\mathrm{d}}$ & $\mathrm{Fe}_{\mathrm{ox}}$ & $\mathrm{Fe}_{\mathrm{t}}$ \\
\hline & & & $\mathrm{g} \mathrm{kg}^{-1}$ & $\bar{L}$ \\
\hline \multirow[t]{7}{*}{ A } & T0 & $5.73 \mathrm{e}$ & $7.11 \mathrm{~b}$ & $37.80 \mathrm{a}$ \\
\hline & $\mathrm{T} 2$ & $7.03 \mathrm{~d}$ & $7.07 \mathrm{~b}$ & $34.92 \mathrm{~b}$ \\
\hline & $\mathrm{T} 4$ & $7.62 \mathrm{c}$ & $7.79 \mathrm{a}$ & $32.76 \mathrm{~d}$ \\
\hline & T6 & $9.85 \mathrm{a}$ & $6.46 c$ & $33.86 \mathrm{c}$ \\
\hline & $\mathrm{T} 8$ & $8.20 \mathrm{~b}$ & $5.70 \mathrm{~d}$ & $32.80 \mathrm{~d}$ \\
\hline & $\mathrm{T} 10$ & $5.36 \mathrm{f}$ & $5.23 \mathrm{e}$ & $32.35 \mathrm{e}$ \\
\hline & $\mathrm{T} 12$ & $4.55 \mathrm{~g}$ & $7.05 \mathrm{~b}$ & $31.10 \mathrm{f}$ \\
\hline $\mathrm{CV}, \%$ & & 1.51 & 1.91 & 0.41 \\
\hline LSD & & 0.24 & 0.29 & 0.32 \\
\hline \multirow[t]{7}{*}{ B } & T0 & $4.50 \mathrm{~d}$ & $5.83 \mathrm{c}$ & $38.35 \mathrm{a}$ \\
\hline & $\mathrm{T} 2$ & $6.80 \mathrm{~b}$ & $7.34 \mathrm{a}$ & $30.95 \mathrm{c}$ \\
\hline & $\mathrm{T} 4$ & $7.00 \mathrm{~b}$ & $6.75 b$ & $32.55 \mathrm{~b}$ \\
\hline & T6 & $7.49 \mathrm{a}$ & $6.40 \mathrm{~b}$ & $31.10 \mathrm{c}$ \\
\hline & $\mathrm{T} 8$ & $5.40 \mathrm{c}$ & $5.48 \mathrm{c}$ & $32.10 \mathrm{~b}$ \\
\hline & $\mathrm{T} 10$ & $3.95 \mathrm{e}$ & $3.03 \mathrm{~d}$ & $30.95 \mathrm{c}$ \\
\hline & $\mathrm{T} 12$ & $3.30 \mathrm{f}$ & $7.00 \mathrm{a}$ & $29.70 \mathrm{~d}$ \\
\hline $\mathrm{CV}, \%$ & & 2.94 & 3.19 & 0.81 \\
\hline LSD & & 0.37 & 0.45 & 0.61 \\
\hline
\end{tabular}

Means in columns followed by the same letter are not different according to Tukey's test $(P \leq 0.05)$.

$\mathrm{Fe}_{\mathrm{d}}$ : Available $\mathrm{Fe}$ extracted by dithionite-citrate-bicarbonate (DCB) method; $\mathrm{Fe}_{\mathrm{ox}}$ : amorphous $\mathrm{Fe}$ extracted with ammonium oxalate; $\mathrm{Fe}_{\mathrm{t}}$ : total $\mathrm{Fe}$ extracted by acid digestion; $\mathrm{CV}$ : coefficient of variation; LSD: least significant difference. 
capacity; this coincides with the characteristics of the parental material of the soil in the present study. Acevedo-Sandoval et al. (2002) reported that $\mathrm{Fe}_{\text {ox }}$ predominates in the upper horizons of Inceptisols and Alfisols. In our study, this parameter showed a higher coefficient of variation compared with $\mathrm{Fe}_{\mathrm{d}}$ and $\mathrm{Fe}_{\mathrm{t}}$ in both horizons. Van Dam et al. (2008) reported that $\mathrm{Fe}_{\mathrm{ox}}$ is considered to be unstable under certain environmental conditions that occur during initial soil formation or in the presence of silicates, which prevent the formation of crystalline Fe oxides.

The $\mathrm{Fe}_{\mathrm{t}}$ contents ranged from 37.80 to $31.10 \mathrm{~g} \mathrm{~kg}^{-1}$ and 38.35 to $29.70 \mathrm{~g} \mathrm{~kg}^{-1}$ for the A and B horizons, respectively (Table 3). Winkler et al. (2016) evaluated the Fe response in rice growing soils (Vertisols, Andisols, and Alfisols) and reported $\mathrm{Fe}_{\mathrm{t}}$ values ranging from 59.3 to $62.4 \mathrm{~g} \mathrm{~kg}^{-1}$. These values were higher than those obtained in our study. A similar behavior of $\mathrm{Fe}_{\mathrm{t}}$ levels was observed in both genetic horizons, and the values decreased as the number of years of slurry application increased.

\section{Ratios of different evaluated forms of $\mathrm{Fe}$}

The content of crystalline Fe oxides obtained from the difference between $\mathrm{Fe}_{\mathrm{d}}$ and $\mathrm{Fe}_{\mathrm{ox}}$ (Parfitt and Childs, 1988) was low, and values were $<3.4 \mathrm{~g} \mathrm{~kg}^{-1}$ in both studied horizons (Table 4). The low oxidization reduction potential in the soil could explain this situation (Smith, 1994). The $\mathrm{Fe}_{\text {ox:d }}$ ratio (Table 3) has been widely used to determine the degree of crystallinity of pedogenic $\mathrm{Fe}$ forms and soil evolution (Kendrick and McFadden, 1996). In general, the progressive weathering of soils leads to a decreased $\mathrm{Fe}_{\text {ox:d }}$ ratio as soil aging advances (Vacca et al., 2003). However, these values are typically high in Andisols ( $>0.75$ ), while more developed soils exhibit values $<0$ (Kleber et al., 2004). In our study, the $\mathrm{Fe}_{\text {ox:d }}$ ratio ranged from 0.66 to 2.12, suggesting that these soils are young and poorly evolved. The $\mathrm{Fe}_{\text {ox:d }}$ values for treatments T2, T4, T6, T8, and T10 were significantly lower $(p \leq 0.05)$ than those in T0 and T12 (Table 4). This is explained by a greater pedological development in both horizons (A and B) as a result of slurry application. However, T2 did not show greater development in the A or B horizons, which might be due to the degradation of the grassland after $12 \mathrm{yr}$ and consequently to decreased bioprocesses. Most of the $\mathrm{Fe}$ in the profile is part of the silicate structure $\left(\mathrm{Fe}_{\mathrm{t}-\mathrm{d}}\right)$ and accounts for $70.91 \%$ to $88.89 \%$ of the total Fe in both genetic horizons.

\section{Chemical and microbiological properties ( $\mathrm{pH}$, electrical conductivity, and organic matter)}

Soil acidity $(\mathrm{pH})$ was significantly higher $(p \leq 0.05)$ in T0 in the A horizon compared with the different evaluated treatments (Table 5). As the time (years) of slurry application increased, $\mathrm{pH}$ became less acidic. Whalen et al. (2000) stated that there is evidence that animal slurries can increase $\mathrm{pH}$ in acid soils due to the buffer effect caused by the content of bicarbonates and organic acids. The $\mathrm{pH}$ values for the B horizon ranged from 6.41 to 6.81 , varying from slightly acidic to almost neutral. It is important to note that there was a slight decrease in acidity in both profiles as depth increased.

Table 4. Ratios of the different Fe forms evaluated for both the A and B genetic horizons of the studied Andisol.

\begin{tabular}{ccccc}
\hline Horizon & Treatment & $\mathrm{Fe}_{\mathrm{d}-\mathrm{ox}}$ & $\mathrm{Fe}_{\text {ox:d }}$ & $\mathrm{Fe}_{\mathrm{t}-\mathrm{d}}$ \\
\hline \multirow{2}{*}{$\mathrm{A}$} & & & $\mathrm{g} \mathrm{kg}^{-1}$ & \\
& $\mathrm{~T} 0$ & - & $1.24 \mathrm{~b}$ & $32.07 \mathrm{a}$ \\
& $\mathrm{T} 2$ & - & $1.01 \mathrm{c}$ & $27.89 \mathrm{~b}$ \\
& $\mathrm{~T} 4$ & - & $1.02 \mathrm{c}$ & $25.14 \mathrm{e}$ \\
& $\mathrm{T} 6$ & 3.39 & $0.66 \mathrm{~d}$ & $24.01 \mathrm{~g}$ \\
& $\mathrm{~T} 8$ & 2.50 & $0.70 \mathrm{~d}$ & $24.60 \mathrm{e}$ \\
& $\mathrm{T} 10$ & 0.13 & $0.98 \mathrm{c}$ & $26.99 \mathrm{c}$ \\
& $\mathrm{T} 12$ & - & $1.55 \mathrm{a}$ & $26.55 \mathrm{~d}$ \\
\hline \multirow{2}{*}{ LSD } & & - & 0.063 & 0.311 \\
\hline \multirow{2}{*}{$\mathrm{B}$} & $\mathrm{T} 0$ & - & $1.30 \mathrm{~b}$ & $33.85 \mathrm{a}$ \\
& $\mathrm{T} 2$ & - & $1.08 \mathrm{c}$ & $24.15 \mathrm{e}$ \\
& $\mathrm{T} 4$ & 0.25 & $0.96 \mathrm{~cd}$ & $25.55 \mathrm{~d}$ \\
& $\mathrm{~T} 6$ & 1.09 & $0.85 \mathrm{de}$ & $23.61 \mathrm{ec}$ \\
& $\mathrm{T} 8$ & - & $1.01 \mathrm{c}$ & $26.70 \mathrm{~b}$ \\
& $\mathrm{~T} 10$ & 0.92 & $0.77 \mathrm{ef}$ & $27.00 \mathrm{~b}$ \\
& $\mathrm{~T} 12$ & - & $2.12 \mathrm{a}$ & $26.40 \mathrm{~b}$ \\
\hline LSD & & - & 0.157 & 0.691 \\
\hline
\end{tabular}

Means in columns followed by the same letter are not different according to Tukey's test $(P \leq 0.05)$.

$\mathrm{Fe}_{\mathrm{d}-\mathrm{x}}$ : Crystalline $\mathrm{Fe}$ oxide; $\mathrm{Fe}_{\text {ox: }}$ : activity index; $\mathrm{Fe}_{\mathrm{t}-\mathrm{d}}$ : silicate $\mathrm{Fe}$; LSD: least significant difference. 
Table 5. Chemical characteristics selected for the genetic horizons of the studied Andisol.

\begin{tabular}{|c|c|c|c|c|}
\hline Horizon & Treatment & $\mathrm{pH}$ & $\mathrm{CE}$ & $\mathrm{OM}$ \\
\hline \multirow{8}{*}{ A } & & & $\mathrm{dS} \mathrm{m}^{-1}$ & $\%$ \\
\hline & T0 & $6.00 \mathrm{~d}$ & $0.29 \mathrm{ab}$ & $10.98 \mathrm{c}$ \\
\hline & $\mathrm{T} 2$ & $6.24 \mathrm{c}$ & $0.32 \mathrm{a}$ & $12.04 \mathrm{~b}$ \\
\hline & $\mathrm{T} 4$ & $6.44 \mathrm{ab}$ & $0.14 \mathrm{c}$ & $11.03 \mathrm{c}$ \\
\hline & T6 & $6.25 b c$ & $0.17 \mathrm{c}$ & $15.50 \mathrm{a}$ \\
\hline & $\mathrm{T} 8$ & 6.38abc & $0.15 \mathrm{c}$ & $15.71 \mathrm{a}$ \\
\hline & $\mathrm{T} 10$ & $6.48 \mathrm{a}$ & $0.13 c$ & $10.99 \mathrm{c}$ \\
\hline & $\mathrm{T} 12$ & $6.53 \mathrm{a}$ & $0.20 \mathrm{bc}$ & $11.12 \mathrm{c}$ \\
\hline $\mathrm{CV}, \%$ & & 1.34 & 22.75 & 3.00 \\
\hline LSD & & 0.19 & 0.10 & 0.87 \\
\hline \multirow{7}{*}{ B } & T0 & $6.41 \mathrm{~b}$ & $0.13 \mathrm{a}$ & $7.10 \mathrm{e}$ \\
\hline & $\mathrm{T} 2$ & $6.46 \mathrm{~b}$ & $0.12 \mathrm{ab}$ & $9.63 b c$ \\
\hline & $\mathrm{T} 4$ & $6.53 \mathrm{ab}$ & $0.09 \mathrm{~d}$ & $8.87 \mathrm{~d}$ \\
\hline & $\mathrm{T} 6$ & $6.81 \mathrm{a}$ & $0.11 \mathrm{bc}$ & $10.17 \mathrm{ab}$ \\
\hline & $\mathrm{T} 8$ & $6.58 \mathrm{ab}$ & $0.11 b c$ & $10.35 \mathrm{a}$ \\
\hline & $\mathrm{T} 10$ & $6.58 \mathrm{ab}$ & $0.09 \mathrm{~d}$ & $9.47 \mathrm{c}$ \\
\hline & $\mathrm{T} 12$ & $6.68 \mathrm{ab}$ & $0.10 \mathrm{~cd}$ & $8.47 \mathrm{~d}$ \\
\hline $\mathrm{CV}, \%$ & & 2.09 & 6.66 & 3.16 \\
\hline LSD & & 0.32 & 0.01 & 0.66 \\
\hline
\end{tabular}

Means in columns followed by the same letter are not different according to Tukey's test $(P \leq 0.05)$.

EC: Electrical conductivity; OM: organic matter; MR: microbiological respiration; CV: coefficient of variation; LSD: least significant difference.

Nonsignificant differences were found $(p \leq 0.05)$ between treatments T4, T6, T8, and T10 (Table 5) for electrical conductivity (EC) in the A horizon. Values ranged from 0.13 to $0.32 \mathrm{dS} \mathrm{m}^{-1}$ with $\mathrm{T} 0$ and $\mathrm{T} 2$ recording the highest values. The EC is significantly influenced by water content, clay content, and the presence of interchangeable ions capable of conducting an electrical current, which also affects the nutritional characteristics of the soil. Wei et al. (2009) indicated that high variations in EC can be explained by unequal applications of amendments or fertilizers. In the B horizon, EC was less variable and values varied between 0.09 and $0.13 \mathrm{dS} \mathrm{m}^{-1}$.

Organic matter contents were higher in the A horizon treatments compared with those in the B horizon (Table 5). Organic C (OC) from grasslands and slurry applications would explain this situation. A similar behavior was observed by Venegas (2008) in an Andisol of the Osorno series in Chile. He indicated that OM content decreases as depth in the profile increases. The OM levels in the A horizon showed significant differences $(p \leq 0.05)$ in all the treatments; T6 and T8 recorded OM levels $>15 \%$. These results are similar to those obtained by Alarcón et al. (2010), who reported similar $\mathrm{OM}$ values in a soil of volcanic origin in an artificial pasture. For the B horizon, OM contents varied between 7.10\% and $10.35 \%$; they were in the lower OM percentage and similar (7.2\%) to those obtained by Fernández et al. (2017) in an Alfisol in the town of San Ignacio, Chile (36 46'51.01" S, 72 00 '29.62" W). A similar trend was observed in both horizons. The T8 treatment recorded the highest OM levels, while T10 and T12 had decreased OM. This effect could be attributed to grassland degradation in T10 and T12. OM can be subjected to leachate losses and the humification processes diminished; therefore, the good use of these organic residues would be based on the quality of the grassland, which in turn would be related to microorganism activity. The lower microbial activity decreases $\mathrm{OM}$ mineralization, restricting $\mathrm{N}$ availability $\left(\mathrm{NH}_{4}^{+}\right.$and $\left.\mathrm{NO}_{3}{ }^{-}\right)$and negatively impacting crop growth (Robertson and Groffman, 2015).

Tables 6 and 7 show correlations between the studied variables. There is a correlation between the different forms of $\mathrm{Fe}$ and the physicochemical properties of the soil under study. Specifically, there is a positive and highly significant correlation $(p \leq 0.001)$ between $\mathrm{OM}$ and the $\mathrm{Fe}_{\mathrm{d}}$ fraction in the A horizon. Conversely, there is a highly significant negative correlation $(p \leq 0.001)$ between $\mathrm{OM}$ and $\mathrm{Fe}_{\mathrm{t}}$. There is a negative correlation between $\mathrm{pH}$ and all the forms of evaluated $\mathrm{Fe}$. This coincides with the results reported by Bronick and Lal (2005). In our study, the negative correlation between $\mathrm{pH}$ and $\mathrm{Fe}_{\mathrm{t}}$ was highly significant $(p \leq 0.001)$ in both genetic horizons.

For the selected physicochemical properties, no correlation was found between EC and the forms of Fe evaluated in both horizons. 
Table 6. Pearson's correlation between different variables for the A horizon of the studied Andisol.

\begin{tabular}{|c|c|c|c|c|c|c|}
\hline Variable & $\mathrm{pH}$ & $\mathrm{CE}$ & OM & $\mathrm{Fe}_{\mathrm{d}}$ & $\mathrm{Fe}_{o x}$ & $\mathrm{Fe}_{\mathrm{t}}$ \\
\hline $\mathrm{pH}$ & 1.0000 & -0.1990 & -0.0890 & -0.1300 & -0.1470 & $-0.6200 * *$ \\
\hline $\mathrm{CE}$ & & 1.0000 & -0.2150 & -0.1870 & 0.3760 & 0.6030 \\
\hline $\mathrm{OM}$ & & & 1.0000 & $0.7980 * *$ & $-0.3760 *$ & -0.0700 \\
\hline $\mathrm{Fe}_{\mathrm{d}}$ & & & & 1.0000 & -0.0190 & 0.0910 \\
\hline $\mathrm{Fe}_{o x}$ & & & & & 1.0000 & 0.2610 \\
\hline $\mathrm{Fe}_{\mathrm{t}}$ & & & & & & 1.0000 \\
\hline
\end{tabular}

EC: Electrical conductivity; $\mathrm{OM}$ : organic matter; $\mathrm{Fe}_{\mathrm{d}}$ : available $\mathrm{Fe}$ extracted by dithionite-citrate-bicarbonate (DCB) method; $\mathrm{Fe}_{\mathrm{ox}}$ : amorphous $\mathrm{Fe}$ extracted with ammonium oxalate; $\mathrm{Fe}_{\mathrm{e}}$ : total $\mathrm{Fe}$ extracted by acid digestion.

$*$,**Significant at the 0.05 and 0.01 probability levels, respectively.

Table 7. Pearson's correlation between different variables for the B horizon of the studied Andisol.

\begin{tabular}{|c|c|c|c|c|c|c|}
\hline Variable & $\mathrm{pH}$ & $\mathrm{CE}$ & $\mathrm{OM}$ & $\mathrm{Fe}_{\mathrm{d}}$ & $\mathrm{Fe}_{\mathrm{ox}}$ & $\mathrm{Fe}_{\mathrm{t}}$ \\
\hline $\mathrm{pH}$ & 1.0000 & 0.1560 & -0.3700 & -0.3910 & -0.0700 & $-0.3500 * *$ \\
\hline $\mathrm{CE}$ & & 1.0000 & -0.0900 & -0.0330 & 0.2730 & 0.5480 \\
\hline $\mathrm{OM}$ & & & 1.0000 & 0.2160 & -0.1740 & $-0.6370^{* *}$ \\
\hline $\mathrm{Fe}_{\mathrm{d}}$ & & & & 1.0000 & $0.6210 * *$ & -0.2410 \\
\hline $\mathrm{Fe}_{o x}$ & & & & & 1.0000 & -0.1000 \\
\hline $\mathrm{Fe}_{\mathrm{t}}$ & & & & & & 1.0000 \\
\hline
\end{tabular}

\section{CONCLUSIONS}

Slurry applications in the soil resulted in a significant increase in the available $\mathrm{Fe}\left(\mathrm{Fe}_{\mathrm{d}}\right)$ contents up to $8 \mathrm{yr}$ in both the $\mathrm{A}$ and $\mathrm{B}$ horizons. However, total $\mathrm{Fe}\left(\mathrm{Fe}_{\mathrm{t}}\right)$ levels decreased as the number of years of application increased.

The amorphous $\mathrm{Fe}\left(\mathrm{Fe}_{\mathrm{ox}}\right): \mathrm{Fe}_{\mathrm{d}}$ ratio $\left(\mathrm{Fe}_{\text {ox: }}\right)$ indicates that these soils are pedologically underdeveloped. It also confirms that slurry application has an anthropogenic effect on its pedogenesis.

There was a positive correlation between organic matter $(\mathrm{OM})$ and $\mathrm{Fe}_{\mathrm{d}}$. This would indicate that the pedogenesis of this soil can be accelerated as a result of increased OM, but conditioned to the bioprocesses related to the state and quality of the grassland.

\section{REFERENCES}

Acevedo, O.A., Cruz, E., Cruz, M., Prieto, F., y Prieto, J. 2014. Sesquióxidos de hierro en bosques templado húmedos del Estado de Hidalgo, México. Revista de la Facultad de Ciencias Agrarias. Universidad Nacional de Cuyo 46(1):109-123.

Acevedo-Sandoval, O., Cruz-Sánchez, M., y Cruz-Chávez, E. 2002. Distribución de óxidos de Fe, Al y Si en horizontes endurecidos de origen volcánico. Agrociencia 36(4):401-409.

Acevedo-Sandoval, O., Prieto, J., Vela-Correa, G., Cruz-Sánchez, M., Ortiz-Hernández, E., Cruz-Sánchez, E., et al. 2011. Óxidos de Fe, Al y Si en "fragipanes" blancos desarrollados en materiales de origen volcánico. Revista de la Sociedad Geológica de España 24(3-4):227-236.

Aguado-Santacruz, G.A., Moreno-Gómez, B., Jiménez-Francisco, B., García-Moya, E. y Preciado-Ortiz, R.E. 2012. Impacto de los sideróforos microbianos y fitosideróforos en la asimilación de hierro por las plantas: una síntesis. Revista Fitotecnia Mexicana 35(1):9-21.

Alarcón, C., Dörner, J., Dec, D., Balocchi, O., López, I. 2010. Efecto de dos intensidades de pastoreo sobre las propiedades hidráulicas de un Andisol (Duric Hapludand). Agro Sur 38(1):30-41.

Besoain, E. 1985. Mineralogía de los suelos volcánicos del centro-sur de Chile. p. 109-302. En Tosso, J. (ed.) Suelos volcánicos de Chile. Instituto de Investigaciones Agropecuarias (INIA), Santiago, Chile.

Bronick, C.J., and Lal, R. 2005. Soil structure and management: a review. Geoderma 124(1-2):3-22.

Chevallier, T., Woignier, T., Toucet, J., and Blanchart, E. 2010. Organic carbon stabilization in the fractal pore structure of andosols. Geoderma 159(1-2):182-188. 
Fernández, C., Celis, J., Stolpe, N., and Sandoval, M. 2017. Nitrogen mineralization in an Alfisol amended with thermoelectrical industry by-products. Chilean Journal of Agricultural Research 77(4):400-405.

Harrington, J.M., and Crumbliss, A.L. 2009. The redox hypothesis in siderophore-mediated iron uptake. Biometals 22(4):679-689.

Hernández, J., y Meurer, E. 1997. Óxidos de hierro en los suelos: sus propiedades y su caracterización con énfasis en los estudios de retención de fósforo. Agrociencia 1(1):1-14.

Kendrick, K.J., and McFadden, L.D. 1996. Comparison and contrast of processes of soil formation in the San Timoteo Badlands with chronosequences in California. Quaternary Research 46(2):149-160.

Kilic, K., Yalcin, H., Durak, A., and Dogan, H.M. 2018. Andisols of Turkey: an example from the Cappadocian Volcanic Province. Geoderma 313:112-125.

Kleber, M., Mikutta, C., and Jahn, R. 2004. Andosols in Germany-pedogenesis and properties. Catena 56(1-3):67-83.

Lu, S., Malik, Z., Chen, D., and Wu, C. 2014. Porosity and pore size distribution of Ultisols and correlations to soil iron oxides. Catena 123:79-87.

Mehra, O.P., and Jackson, M.L. 1960. Iron oxide removal from soils and clays by a dithionite-citrate system buffered with sodium bicarbonate. Clays and Clay Minerals 7(1):317-327.

Moustakas, N.K., and Georgoulias, F. 2005. Soils developed on volcanic materials in the Island of Thera, Greece. Geoderma 129(3-4):125-138.

Murad,E., and Fischer, W.R. 1988. The geobiochemical cycle of iron.p. 1-18. In Stucki, J.W., Goodman, B.A., and Schwertmann, U. (eds.) Iron in soils and clay minerals. Nato Science Series C: Mathematical and Physical Sciences Vol. 217. D. Reidel Publishing Company, Dordrecht, The Netherlands.

Parfitt, R.L., and Childs, C.W. 1988. Estimation of forms of Fe and Al: a review and analysis of contrasting soils by dissolution and Mossbaïer methods. Australian Journal of Soil Research 26(1):121-144.

Pérez, N., Jaramillo, D., Ruiz, O., y Parra, L. 2018. Extracciones selectivas y secuenciales de Al, Fe y Si en un Andisol del oriente antioqueño, Colombia. Revista de la Facultad de Ciencias 7(1):124-142.

Pizarro, C.G. 2000. Mineralogía de los óxidos de hierro y equilibrios de intercambio catiónico en suelos volcánicos chilenos. Tesis Doctor en Química. Universidad de Santiago de Chile, Facultad de Química y Biología, Santiago, Chile.

Robertson, G.P., and P.M. Groffman. 2015. Nitrogen transformations. p. 421-446. In Paul, E.A. (ed.) Soil microbiology, ecology, and biochemistry. $4^{\text {th }}$ ed. Academic Press, London, UK.

Sadzawka, A., Carrasco, M.A., Grez, R., Mora, M., Flores, H., y Neaman, A. 2006. Métodos de análisis recomendados para los suelos de Chile: Revisión 2006. Serie Actas INIA N³4. Instituto de Investigaciones Agropecuarias, INIA La Platina, Santiago, Chile.

Salazar, F., Dumont, J.C., Chadwick, D., Saldaña, R., and Santana, M. 2007. Characterization of dairy slurry in Southern Chile farms. Agricultura Técnica (Chile) 67:155-162.

Salazar, F.J., Dumont, J.C., Santana, M.A., Pain, B.F., Chadwick, D.R., y Owen, E. 2003. Prospección del manejo y utilización de efluentes de lecherías en el sur de Chile. Archivos de Medicina Veterinaria 35(2):215-225.

Sandoval, M., Doner, J., Seguel, O., Cuevas, J., y Rivera, D. 2012. Métodos de análisis físicos de suelos. Publicaciones Departamento de Suelos y Recursos Naturales N5.80 p. Universidad de Concepción, Facultad de Agronomía, Chillán, Chile.

Sánchez, J.A., y Rubiano, Y. 2015. Procesos específicos de formación en Andisoles, Alfisoles y Ultisoles en Colombia. Revista Escuela de Ingeniería de Antioquia (EIA) 12(2):E85-E97.

Schwertmann, U. 1964. Differenzierung der eisenoxide des bodens durch extraktion mit ammoniumoxalat-lösung. Journal of Plant Nutrition and Soil Science-Zeitschrift fur Pflanzenernahrung und Bodenkunde 105(3):194-202.

Shoji, S., Dahlgren, R., and Nanzyo, M. 1993. Genesis of volcanic ash soils. p. 37-71. In Shoji, S., Nanzyo, N., and Dahlgren, R. (eds.) Volcanic ash soils: genesis, properties and utilization. Developments in Soil Science $\mathrm{N}^{\circ} 21$. Elsevier Science Publishers B.V., Amsterdam, The Netherlands.

Smith, B.F.L. 1994. Characterization of poorly ordered minerals by selective chemical methods. p. 333-357. In Wilson, M.J. (ed.) Clay mineralogy spectroscopic and chemical determinative methods. Chapman and Hall, London, UK.

Solís, S. 1998. Bioactivadores orgánicos y quelato de hierro en el cultivo de papa (Solanum tuberosum L.) var. Mondial. Tesis Ingeniero Agrónomo. Universidad Autónoma Agraria “Antonio Narro", División de Ingeniería, Departamento de Suelos, Saltillo, México.

Stolpe, N.B. 2006. Descripciones de los principales suelos de la VIII Región de Chile. Publicaciones del Departamento de Suelo y Recursos Naturales $N^{\circ} 1$. Universidad de Concepción, Facultad de Agronomía, Chillán, Chile.

Stoppe, N., Amelung, W., and Horn, R. 2015. Chemical extraction of sedimentary iron oxy(hydr)oxides using ammonium oxalate and sodium dithionite revisited - an explanation of processes in coastal sediments. Agro Sur 43(2):11-17.

Torrent, J., Schwertmann, U., and Schudlze, D. 1980. Iron oxide mineralogy of some soils of two river terrace sequences in Spain. Geoderma 23:191-208.

Tsai, C.C., Chen, Z.S., Kao, C.I., Ottner, F., Kao, S.J., and Zehetner, F. 2010. Pedogenic development of volcanic ash soils along a climosequence in northern Taiwan. Geoderma 156(1-2):48-59. 
Vacca, A., Adamo, P., Pigna, M., and Violante, P. 2003. Genesis of Tephra-derived soils from the Roccamonfina volcano, south central Italy. Soil Science Society of America Journal 67(1):198-207.

Van Dam, R.L., Harrison, J.B., Hirschfeld, D.A., Meglich, T.M., Li, Y., and North, R.E. 2008. Mineralogy and magnetic properties of basaltic substrate soils: Kaho'olawe and Big island, Hawaii. Soil Science Society of America Journal 72(1):244-257.

Vazques, J., Macías, F., y Menjivar, J.C. 2014. Formas de hierro y aluminio en suelos con diferentes usos en la zona norte del departamento de Magdalena, Colombia. Acta Agronómica 63(4):352-360.

Venegas, A.P. 2008. Características de la materia orgánica de suelos de praderas naturales y cultivadas en la IX Región. Memoria de título de Químico. Universidad de Chile, Facultad de Ciencias Químicas y Farmacéuticas, Santiago, Chile.

Wei, Y.C., Bai, Y.L., Jin, J.Y., Zhang, F., Zhang, L.P., and Liu, X.Q. 2009. Spatial variability of soil chemical properties in the reclaiming marine foreland to yellow sea of China. Agricultural Sciences in China 8(9):1103-1111.

Whalen, J.K., Chang, C., Clayton, G.W., and Carefoot, J.P. 2000. Cattle manure amendments can increase the pH of acid soils. Soil Science Society of America Journal 64(3):962-966.

Winkler, P., Kaiser, K., Kölbl, A., Kühn, T., Schad, P., Urbanski, L., et al. 2016. Response of Vertisols, Andosols, and Alisols to paddy management. Geoderma 261:23-35. 